\title{
INQUIRY-BASED PHYSICS EDUCATION BY USING SCIENCE LEARNING SYSTEM XPLORER GLX
}

\author{
Violeta Šlekienè, Loreta Ragulienè \\ University of Siauliai, Lithuania \\ E-mail: fk@fm.su.It
}

\begin{abstract}
In order to improve students' competencies of natural science must be consistent and systematic development of learning methods and strategies. Since Physics is an experimental science, the role of practical activities in physics education is very important. Experimental activities are one of the main Physics teaching/learning methods. One of these methods is inquiry-based learning, in which students answer research questions through data analysis. Computer-based data logging is a powerful strategy for the teaching and learning of physics. It helps to deliver a deep and meaningful physics education, increasing the interaction between the student and the concepts under investigation.

This article deals with Physics experimental works by using the Xplorer GLX on different levels (confirmation, structured, guided and open inquiry) of inquiry-based learning. The research methodology is based on the provisions of the constructivist education theory underlying the structured, guided and open explorations as an effective educational technology, which promotes a positive attitude towards science, helps to apply the acquired knowledge in different situations, develops higher-level thinking skills, encourages active learning processes.

Experimental activities use an inquiry-based approach, based on a small-scale research activity through different levels of inquiry using science learning system Xplorer GLX. The aim of each experimental activity is to gain practical research skills, master research methods, learn how to work safely with the physical equipment, to collect, process and convey the results of experiment and link them to theoretical models, to make generalizations and conclusions. One physics laboratory work (Capacitor Discharge) at the level II, as structured exploration, and level III, as guided exploration, using science learning system Xplorer GLX is presented. A key focus is on learning through collaborative work, supported by practical work. Students work together to collect \& analyse data and present their results.

Key words: Xplorer GLX, Inquiry-based education, four levels of Inquiry, physics education, computer based experiment.
\end{abstract}

\section{Introduction}

In recent years, observed quite significant changes in Science Education. Renewed General Programme of Lithuanian secondary education was approved in 2011. The Programme focused on the quality of education: education content meets the changing needs of society and shall maintain the harmony between education levels; education content accessible and efficient throughout the education system, education content changes continuously (Jakimovas, 2011). Renewed physics curriculum highlights the main idea - change in processes at school: the transition from learning formulas and training to apply them into deeper understanding of the phenomena and laws, the ability to apply them in new, non-standard situations, solve problems, develop creativity, move from the practical works according to a detailed description into planning and carrying out self research. Students who have chosen a general physics course, it is proposed to carry out a minimum of 4 - 6 laboratory works of which at least two should be carried out as a self-study. Chosen an advanced physics course is proposed to carry out $6-10$ 
Violeta ŠLEKIENĖ, Loreta RAGULIENĖ. Inquiry-based Physics Education by Using Science Learning System Xplorer GLX

PROBLEMS

OF EDUCATION

IN THE $21^{\text {st }}$ CENTURY Volume 57, 2013

experiments works of which at least four should be carried out independently as a research. It is recommended to perform several computers-supported lab. Works by using new technologies, which are rapidly penetrating into the everyday life of young people. No coincidence that educational theoreticians and practitioners in the spotlight - effective adaptation and usage of new technologies in educational practice.

Since Physics is an experimental science, the role of practical activities in physics education has been often paid attention by research studies (Bernhard, 2003; Harms, 2000; Sassi, 2001). Experimental students' activities are one of the keys Science teaching/learning methods. These methods can be attributed to all of constructivism based learning technologies, which are called differently in the scientific literature: Discovery learning (Anthony, 1973, Bruner, 1961); Problem-based learning (Barrows, Tamblyn, 1980; Schmidt, 1983); Inquiry based learning (Papert, 1980, Rutherford, 1964); Experiential learning (Kolb, Fry, 1975; Boud, Keogh, Walker, 1985) or just Constructivist learning (Steffe, Gale Hillsdale,1995; Jonassen, 1991).

Inquiry is an active learning process in which students answer research questions through data analysis. One might argue that the most authentic inquiry activities are those in which students answer their own questions through analysing data they collect independently. However, an activity can still be inquiry based when the questions and data are provided, as long as students are conducting the analysis and drawing their own conclusions.

In the late 1960s and early 1970s, researchers developed a tool for determining the level of inquiry promoted by a particular activity known as Herron's Scale (Herron, 1971). The assessment tool is based on a simple principle: How much is "given" to the student by the teacher or activity instructions? Using this question as a framework, Herron's Scale describes four levels of inquiry: exploration, directed, guided, and open-ended.

Table 1 (Bell, Smetana, Binns, 2005) presents a modified version of the four-level model of inquiry, which is used to assess instructional activities. The four-level model illustrates how inquiry- based activities can range from highly teacher directed to highly student centered, based on the amount of information provided to the student. The salient feature of this model is the question, "How much information is given to the student?"

Using this framework as a guide, lab activities can be designed at varying levels of inquiry, depending on wording and presentation. This model allows the teacher to tailor inquiry lessons to the particular readiness levels of the class. For instance, a Level 1 activity can become a Level 2 by having students complete it prior to learning the targeted concept, and a Level 2 activity can be revised easily to Level 3 simply by removing the procedural directions.

Table1. Modified version of the four-level model of inquiry.

\begin{tabular}{lccc}
\hline \multicolumn{4}{c}{ How much information is given to the student? } \\
\hline Level of inquiry & Question & Procedure & Solution \\
\hline 1 & Given & Given & Given \\
\hline 2 & Given & Given & Open \\
\hline 3 & Given & Open & Open \\
\hline 4 & Open & Open & Open \\
\hline
\end{tabular}

The degree of complexity in an inquiry activity also varies, depending on the level of openness and the cognitive demands required.

Bianchi and Bell (2008) identify four major levels of inquiry: confirmation, structured, guided and open (Table 2). 
Table 2. The four levels of inquiry and the information given to the student in each one.

\begin{tabular}{|c|c|c|c|}
\hline Inquiry Level & Question & Procedure & Solution \\
\hline $\begin{array}{l}1 \text { - Confirmation Inquiry } \\
\text { Students confirm a principle through an activity when the results are known } \\
\text { in advance. }\end{array}$ & [ & [ & 0 \\
\hline $\begin{array}{l}2 \text { - Structured Inquiry } \\
\text { Students investigate a teacher-presented question through a prescribed } \\
\text { procedure. }\end{array}$ & प & Q & \\
\hline $\begin{array}{l}3 \text { - Guided Inquiry } \\
\text { Students investigate a teacher-presented question using student designed/ } \\
\text { selected procedures. }\end{array}$ & 口 & & \\
\hline $\begin{array}{l}4 \text { - Open Inquiry } \\
\text { Students investigate questions that are student formulated through student } \\
\text { designed/selected procedures. }\end{array}$ & & & \\
\hline
\end{tabular}

The simplest, Level 1, is sometimes referred to as a confirmation activity. At this level, students are provided the question and procedure, and the expected results are known in advance. For instance, lab activities presented at the end of the chapter to verify a concept that has already been taught fall into this category.

In a Level 2 activity (structured inquiry), students investigate a teacher-presented question through a prescribed procedure. Both Level 1 and 2 activities are commonly referred to as "cookbook labs," because they include step-by-step instructions, but Level 2 activities answer a research question. The difference between a Level 1 and Level 2 activities can be a matter of timing - a confirmation lab can become a structured inquiry lab simply by presenting the lab before the target concept is taught. Note that the majority of laboratory investigations in most textbooks are written at Level 1 or Level 2. Including low-level inquiry activities in the curriculum is not necessarily a problem, as long as they are not used to the exclusion of higher levels. After all, students are able to take greater ownership of their own learning, make authentic decisions, and construct meaning for themselves at the higher levels of inquiry.

A Level 3 activity (guided inquiry), again, features a teacher presented question but leaves the methods and solutions open to students. This level of inquiry requires students to design or select the procedure to carry out the investigation. Students typically get very little practice in designing their own investigations; therefore, guided inquiries have the potential to take student engagement and ownership of the lab to a new level. Furthermore, guided inquiry activities can be easily created from cookbook labs simply by removing the step-by-step directions and requiring students to come up with their own methods for answering the research question. The teacher should approve student procedures before the investigation is conducted and be sure that proper safety guidelines are followed.

Problems, solutions, and methods are left to the student in a Level 4 activity (open inquiry). Science fair projects are perhaps the most common form of Level 4 inquiries in science classrooms. Students investigate student-formulated, topic-related questions and use their own procedures. Assuming that students have had experience completing inquiry activities at Levels $1-3$, they should be prepared to tackle Level 4 investigations.

Lederman, J. S., (2011) presents the 5 E's Learning Cycle, which is fully integrated in all levels of inquiry. By being thoughtfully interwoven in each level, the 5 E's help students achieve the highest level of learning in each and every investigation, no matter which levels teachers choose to implement. 
Violeta ŠLEKIENĖ, Loreta RAGULIENĖ. Inquiry-based Physics Education by Using Science Learning System Xplorer GLX

PROBLEMS

OF EDUCATION

IN THE $21^{\text {st }}$ CENTURY

Volume 57, 2013

Engagement: Students are presented with unfamiliar phenomena, objects, events and/ or questions to pique their curiosity and have them make connections with what they already know. During the engagement phase, students become mentally and physically engaged. They raise questions, identify problems to solve, and consider plans to find answers to their questions. Teachers are able to ascertain prior knowledge and elicit misconceptions.

Exploration: During this phase, students are provided with a common base of experiences. They actively examine and manipulate objects and phenomena through direct investigations organized by the teacher. Exploration is part of every level of inquiry.

Explanation: During this phase, students explain their understanding of the concepts and processes they have been exploring. They have opportunities to verbally explain new concepts and /or demonstrate new skills and abilities. In every level of inquiry students are asked to explain and conclude during and after every investigation. Students are prompted to explain "how they know" their predictions make sense and to anticipate what they would do differently "next time."

Elaboration: In this phase of the model, students are given opportunities to apply concepts in new contexts or situations in order to develop deeper understandings. Students take part in activities that extend conceptual understandings and that allow them to practice new skills. They become involved in the more open-ended inquiry, problem solving, and decision making. In this phase, students may design and carry out their own investigations. At every level of inquiry, students are encouraged to "Find Out More" and to "Think of Another Question" as a means to extend and elaborate on their learning.

Evaluation: In this final phase, students assess their knowledge, skills, and abilities. Activities permit evaluation of student development, lesson effectiveness, and future instructional adjustments. Formal and informal evaluation should occur at every phase and level of inquiry.

On the other hand computer-based teaching can help us deliver a deep and meaningful physics education, increasing the interaction between the student and the concepts under investigation. Interactive, computer-based experience cannot replace the real laboratory work but can enhance the learning process of many students, help them find the relation between the theoretical principles and the observed behaviour.

For more effective computer-based teaching Lithuanian secondary schools have been equipped with three types of science learning systems, such as Xplorer GLX, Nova and Spark, with the necessary teaching equipment (kits of kinematics and dynamics, equipment for gas laws testing, resistance measuring sets, counters of background radioactivity, etc.) and electronic sensors (distance, force, pressure, charge, current, voltage, magnetic field, rotary, photogate, microphone, temperature, etc.).

\section{Problem}

In order to improve students' competencies of natural science must be consistent and systematic development of learning methods and strategies. Since Physics is an experimental science, the role of practical activities in physics education is very important. Experimental activities are one of the main Physics teaching/learning methods. One of these methods is inquiry-based learning, in which students answer research questions through data analysis. Computer-based data logging is a powerful strategy for the teaching and learning of physics. It helps to deliver a deep and meaningful physics education, increasing the interaction between the student and the concepts under investigation. The main problem is how to perform Physics experimental works by using the Xplorer $G L X$ on different levels of inquiry-based learning. 
The object of the research is Physics experimental works using Xplorer GLX.

The main goal - to present Physics laboratory activities at different levels of inquiry using science learning system Xplorer GLX.

\section{Research Methodology}

The research methodology is based on the provisions of the constructivist education theory underlying the structured, guided and open exploration as an effective educational technology, which promotes a positive attitude towards science, helps to apply the acquired knowledge in different situations, develops higher-level thinking skills, encourages active learning processes.

Experimental activities use an inquiry based (IB) approach, based on a small-scale research activity. One physics laboratory work (Capacitor Discharge) at the level II, as structured exploration, and level III, as guided exploration, using science learning system Xplorer GLX is presented.

In inquiry based learning the process will be explained by employing five "E's" (Lederman, 2011). They are: Engage - Explore - Elaborate - Evaluate. A key focus will be on learning through collaborative work, supported by practical work. Students will work together to collect $\&$ analyse data and present their results.

\section{Research Results}

\section{Science Learning Systems: Xplorer GLX}

The Xplorer GLX (Figure 1) is a data collection, graphing, and analysis tool designed for science students and educators. The Xplorer GLX is fully functional stand-alone handheld computing device for science. It also operates as a sensor interface when connected to a desktop or laptop computer running the Data Studio software. An optional mouse, keyboard, or printer can be connected to the Xplorer GLX's USB ports. The Xplorer GLX contains an integrated speaker for sound generation and a stereo signal output port for optional headphones or amplified speakers. The Xplorer GLX supports up to four sensors simultaneously, in addition to two temperature probes and a voltage probe connected directly to specialized ports (Explorations in Physics, 2007).

Xplorer GLX key sensors, which are used in physics, are a motion, force, voltage / current, absolute pressure / temperature sensor (Figure 2) and others.

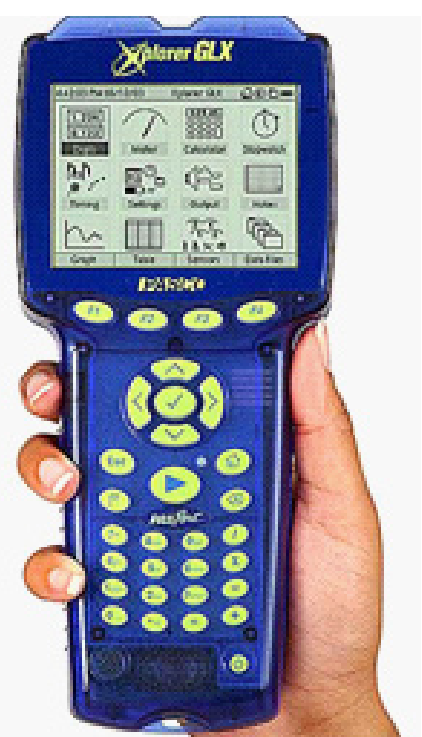

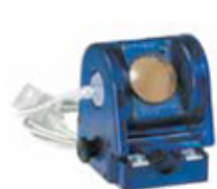

A

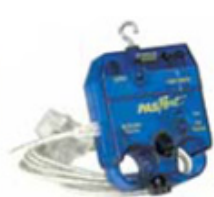

B

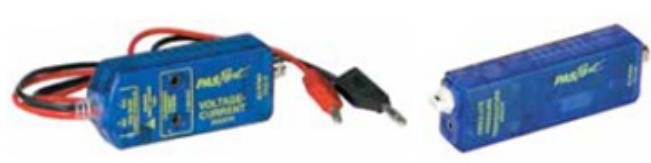

$\mathrm{C}$
$\mathrm{D}$

Figure 2. Xplorer GLX Sensors. A - movement sensor, B - force sensor, C - voltage/current sensor, D - absolute pressure/temperature sensor. 
Violeta ŠLEKIENĖ, Loreta RAGULIENE். Inquiry-based Physics Education by Using Science Learning System Xplorer GLX

PROBLEMS

OF EDUCATION

IN THE $21^{\text {st }}$ CENTURY

Volume 57, 2013

In some cases, the GLX may automatically launch the Graph or other display when you plug in a sensor. An attachment of Xplorer GLX with a suitable sensor created a powerful system for collection, analysis and display of experimental data. It is easy to use and allows the experimental data to be displayed as: digital meters, analog meters, graphs and tables.

The software of Xplorer GLX provides the possibility for further data analysis such as curve fitting, derivation, integration and user defined functions.

\section{Laboratory Activity "Capacitor Discharge"}

The aim of each laboratory work is to gain practical research skills, master research methods, learn how to work safely with the physical equipment, to collect, process and convey the results of experiment and link them to theoretical models, to make generalizations and conclusions.

The lab work Capacitor Discharge is carried out at the level II as structured exploration. Consistent instructions of work performance and a list of measures are provided for students. On the basis of the objective, the hypotheses are verified, ie knowing the functioning principle of condenser, graph of voltage versus time $U=f(t)$ is obtained and the time constant of the condenser capacitance is calculated. The lab work is proposed to perform followed by teaching condenser and its principle of operation. It can be performed as extending and deepening physics knowledge. As the results of this activity are not known in advance, there is the opportunity for discussion in groups. Analysis of results and discussion effective when work is done in pairs, or in groups of 3-5 students. The phenomenon of capacitor discharge, the capacitive time constant and its physical meaning is practically ascertained in this experiment. Skills of experimentation, graph plotting, data acquisition and analysis are formed.

After the execution of lab activity students will know the phenomenon of the condenser discharge, according to the instructions will be able to draw up measures for work, will pay to get voltage $\mathrm{U}=\mathrm{f}(\mathrm{t})$, and the logarithm $\ln \left(\mathrm{U} / \mathrm{U}_{0}\right)=\mathrm{f}(\mathrm{t})$ versus time, to determine the capacitive time constant and will be able to explain its physical meaning.

It was prepared the worksheets which help students incorporate electronic data collection into science experiments when using the Xplorer GLX learning system. Each worksheet has the following parts: equipment list; purpose; background; safety reminders; procedure, analysing the data, lab report.

In this experiment the circuit is created and the voltage probe is connected to the voltage port of Xplorer GLX (Figure 3). The GLX will measure and graph voltage over time as the capacitor discharges. From the collected data the capacitive time constant will be determined.

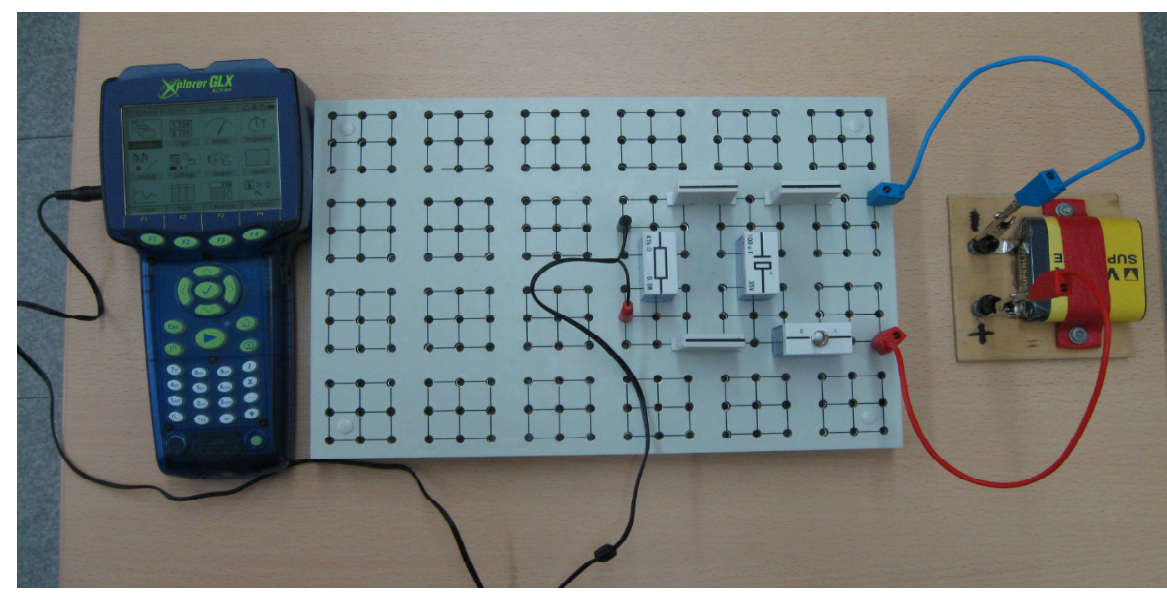

Figure 3: The experiment circuit. 
In order to charge the capacitor, it is temporarily connected to the battery and keep the $\mid$\begin{tabular}{l} 
PROBLEMS \\
OF EDUCATION \\
IN THE 21 $1^{\text {st }}$ CENTURY \\
Volume 57, 2013 \\
\hline 139
\end{tabular} connection for about 5 seconds. Disconnect the terminal of the battery and immediately start data collection. GLX screen monitor plot graph (Figure 4).

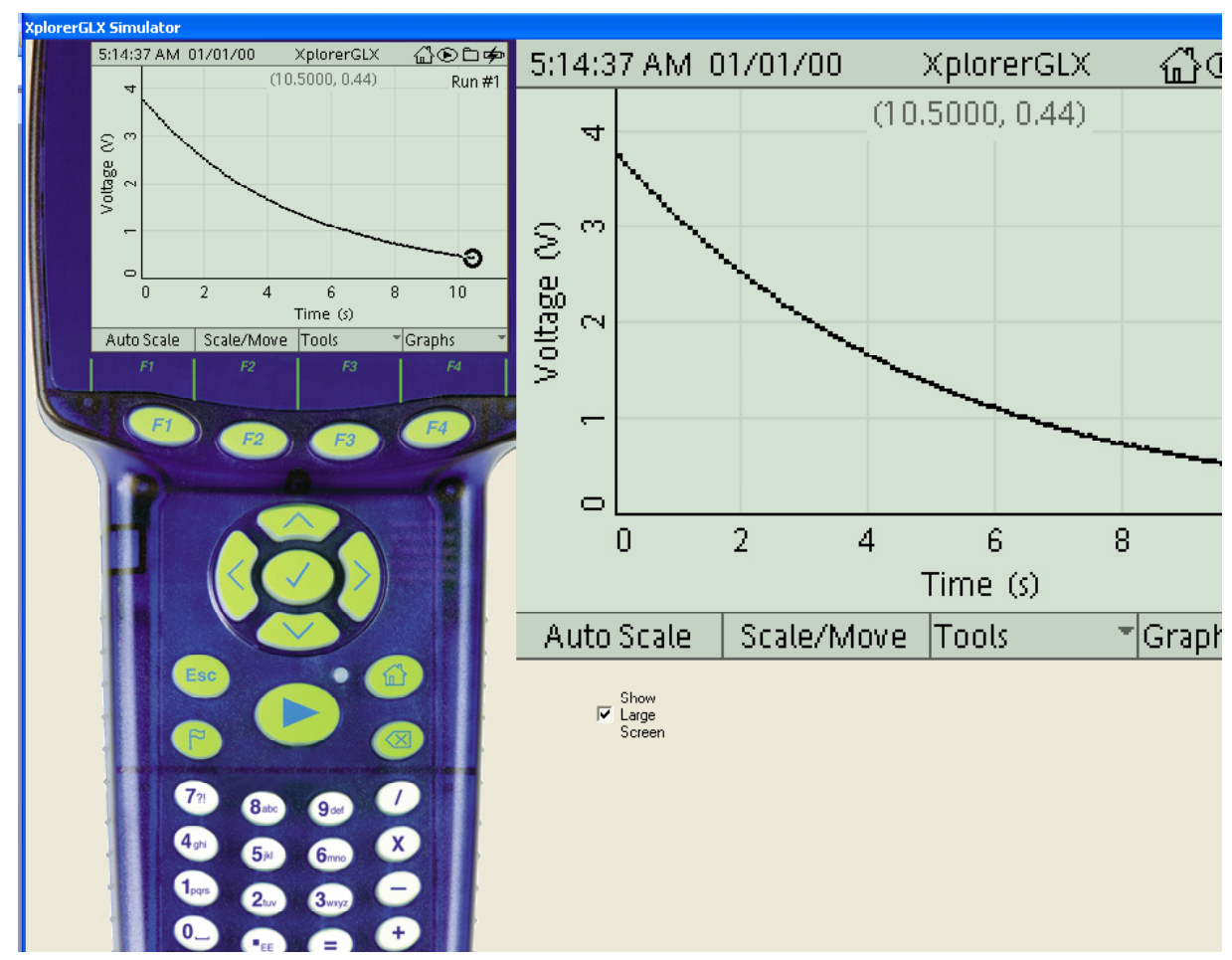

Figure 4. Graph plotting.

When the capacitor discharge voltage varies according to an exponential law:

where $\mathrm{U}$ - voltage at time $\mathrm{t}, \mathrm{U}_{0}$ - voltage at time $\mathrm{t}=0$.

$$
U=U_{0} e^{-\frac{t}{R C}} U=U_{0} e^{\frac{t}{R C}}
$$

After the logarithms of this equation we get:

$$
\ln \left(\frac{U}{U_{0}}\right)=-\frac{t}{R C}
$$

where $\tau=\frac{1}{R C} \tau=\frac{1}{R C}$ - capacitive time constant $\left(\mathrm{s}^{-1}\right)$. The minus sign indicates that the voltage decreases over time.

Then we can write

$$
\ln \left(\frac{U}{U_{0}}\right)=-\tau t
$$

These logarithmic function over time is a straight line, whose slope $\tau=\frac{1}{R C}$.

This slope, which physical meaning is capacitive time constant $\tau$, is found experimentally.

GLX screen plot function $\ln \left(\mathrm{U} / \mathrm{U}_{0}\right)$ versus time $\mathrm{t}$ graph. The slope of the best-fit line equals $\tau$ ( $\tau=(0.205 \pm 1.03$ 10-4) s-1, Fig. 5).

After the experiment, the findings about the dependence of voltage versus time $U=f(t)$, 
Violeta ŠLEKIENĖ, Loreta RAGULIENĖ. Inquiry-based Physics Education by Using Science Learning System Xplorer GLX

PROBLEMS

OF EDUCATION

IN THE $21^{\text {st }}$ CENTURY

Volume 57,2013

when the capacitor is discharged, about the capacitive time constant and its physical meaning are done.

Depth investigation of the condenser discharge can be carried out at the level III as Guided investigation. Research topic is known, but the research process is not presented. Students provide the necessary tools to carry out the experiment and the framing of the problem. Students formulate a hypothesis and plan workflows themselves. Work in groups is effective, as developed communication skills, searching for the correct workflow method.

One group of students is suggested to repeat the experiment with different resistors and to make a graph of $\mathrm{R}$ versus $\tau$. Then they have to make a conclusion about the relationship between time constant and resistance.

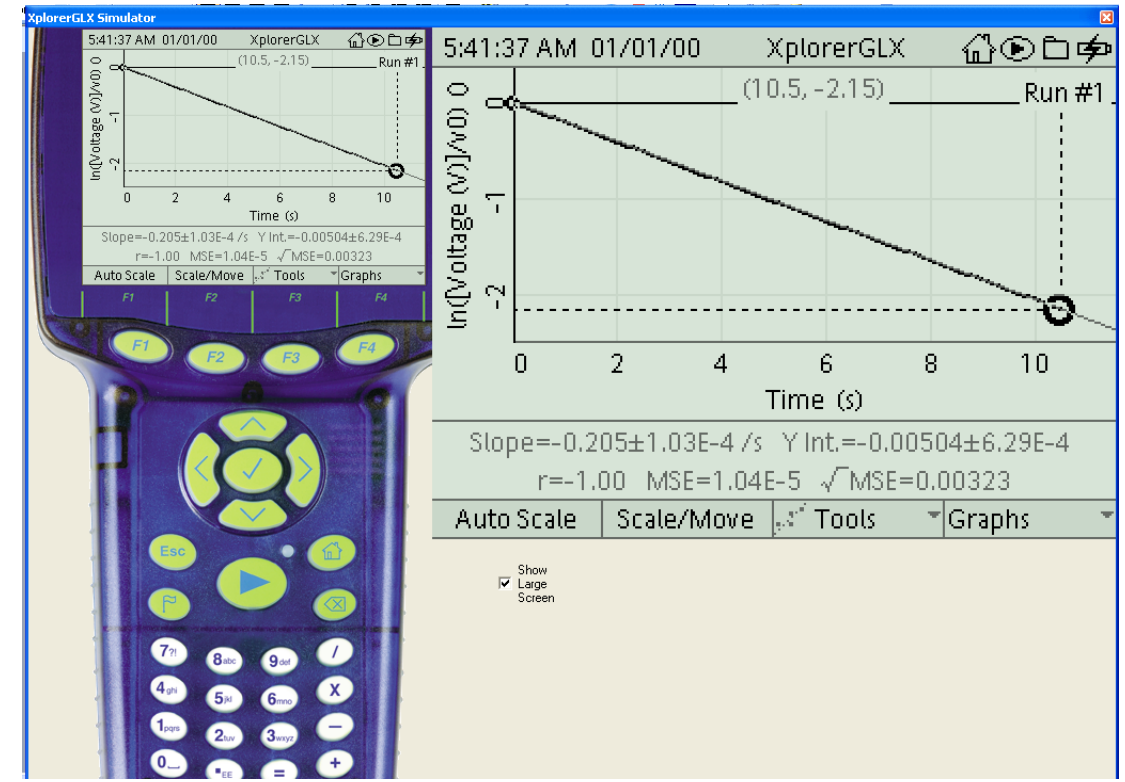

Figure 5: Determination of the capacitive constant $\mathrm{T}$ from graph $\ln \left(\mathrm{U} / \mathrm{U}_{0}\right)$ versus time.

Another group is suggested to repeat the experiment with different capacitors and to make a graph of $\mathrm{C}$ versus $\tau$. Then they have to make a conclusion about the relationship between time constant and capacitance.

Students in groups decide what to investigate, how to investigate it, and how to interpret the results they generate.

\section{Conclusions}

By performing Physics laboratory activities at different levels of inquiry and using science learning system Xplorer $G L X$ theoretical knowledge are strongly related with practical results. Laboratory works are more visual, the data are easy processing. Using science learning system Xplorer GLX the data are displayed in graphical form in real time, so that students get immediate feedback and see the data in an understandable form that can discussed.

Inquiry based learning motivates students to be not passive observers, but active participants of the education process. Research carried out according to the different levels of inquiry allows teachers to individualize and differentiate the learning process. Individualization allows to take into account the student's needs, reveals of individual talents, encourages each student's learning motivation. Differentiation allows to divide students into groups based on the same skill level or mixed groups, where pupils that are more able to help students who are less capable. 


\section{References}

Anthony, W. S. (1973). Learning to discover rules by discovery. Journal of Educational Psychology, 64, $325-328$

Banchi, H., Bell, R. (2008). The Many Levels of Inquiry. Science and Children, 46 (2), 26-29.

Barrows, H. S., Tamblyn, R. M. (1980). Problem-based learning: An approach to medical education. New York: Springer.

Bell, R. L., Smetana, L., \& Binns, I. (2005). Simplifying inquiry instruction: Assessing the inquiry level of classroom activities. The Science Teacher, 72 (7), 30-33.

Bernhard, J. (2003). Physics learning and microcomputer based laboratory (MBL): Learning effects of using MBL as a technological and as a cognitive tool, Science Education Research in the Knowledge Based Society, Dordrecht: Kluwer, 313-321.

Bruner, J. S. (1961). The art of discovery. Harvard Educational Review, 31, 21-32.

Constructivism in education (1995). Eds. L. Steffe, J. Gale Hillsdale, NJ: Lawrence Erlbaum Associates, Inc.

Explorations in Physics (2007). PASCO [2013-09-21]. Retrieved from

http://store.pasco.com/pascostore/showdetl.cfm?\&DID=9\&Product_ID=53202\&Detail=1.

Harms, U. (2000). Virtual and remote labs in physics education. Proceedings of the Second European Conference on Physics Teaching in Engineering Education, 14-17 June, in Budapest.

Herron, M. D. (1971). The nature of scientific inquiry. The School Review, 79, 171-212.

Jakimovas, A. (2011). VUBP atnaujinimas - žingsnis kokybės link. Vidurinio ugdymo bendrosios programos. Informacinis leidinys „Švietimo naujienos “, 3 (303) priedas.

Jonassen, D. (1991). Objectivism vs. constructivism. Educational Technology Research and Development, 39 (3), 5-14.

Kolb, D. A., Fry, R. (1975). Toward an applied theory of experiential learning. Studies of group process. Ed. C. Cooper. New York: Wiley, 33-57.

Lederman, J. S. (2011). Levels of inquiry and the 5 E's learning cycle model. Monterey, CA: National Geographic School Publishing.

Papert, S. (1980). Mindstorms: Children, computers, and powerful ideas. New York: Basic Books.

Rutherford, F. J. (1964). The role of inquiry in science teaching. Journal of Research in Science Teaching, $2,80-84$

Sassi, E. (2001). Lab-work in physics education and informatic tools: advantages and problems. In: Pinto, R. \& Surinach, S. (Eds), Physics Teacher Education Beyond, 57-64. Elsevier, Paris.

Schmidt, H. G. (1983). Problem-based learning: Rationale and description. Medical Education, 17, 1116.

Advised by Naglis Švickus, SMC “Scientia Educologica”, Lithuania

Received: September 25, 2013

Accepted: December 06, 2013

Violeta Šlekienė $\quad$ PhD., Associate Professor, Faculty of Natural Sciences, Šiauliai University, 19 P. Visinskio Street, LT-77156 Siauliai, Lithuania.

Phone: +370 41595721.

E-mail: fk@fm.su.It

Website: http://www.su.It/ This e-mail address is being protected from spambots. You need JavaScript enabled to view it

Loreta Raguliené

PhD., Associate Professor, Department of Physics, Faculty of Natural Sciences, Šiauliai University, 19 P. Visinskio Street, LT-77156 Siauliai, Lithuania.

Phone: +37041595721 .

E-mail: fk@fm.su.lt

Website: http://www.su.It/ 